\title{
PROSEDUR PEMBUKAAN REKENING TABUNGAN PADA BANK NAGARI CABANG SYARIAH PADANG
}

\author{
Sri Wardianti, Mariani St.B Tanjung \\ Akademi Keuangan dan Perbankan Padang \\ mstbtanjung@gmail.com
}

\begin{abstract}
ABSTRAK
Tujuan dari penelitian ini adalah untuk mengetahui prosedur pembukaan rekening tabungan pada Bank Nagari Cabang Syariah Padang. Dalam menganalisa data, penulis menggunakan metode analisa data kualitatif sebagai metode penelitian yang menjelaskan secara deskriptif mengenai prosedur pembukaan rekening tabungan pada Bank Nagari Cabang Syariah Padang. Metode analisa ditinjau dari dua segi yang berbeda yaitu antara teori dan praktek yang perlu dipertemukan sehingga dapat diketahui sejauh mana pelaksanaanya, apakah perbedaan yang timbul menyangkut prinsip dasar konsep itu sendiri. Dengan menganalisa perbandingan, pertanyaan itu akan terjawab dan selanjutnya hasil analisa itu dipergunakan sebagai dasar pengambilan kesimpulan dan saran. Bank Nagari Cabang Syariah Padang merupakan badan/lembaga keuangan yang menjalankan kegiatan usahanya berdasarkan prinsip syariat Islam. Yang didirikan dengan maksud dan tujuan yakni untuk membantu dan mendorong pertumbuhan perekonomian dan pembangunan daerah.
\end{abstract}

Kata Kunci: Rekening, Tabungan

\section{PENDAHULUAN}

Dengan diberlakukannya Undang-Undang No. 10 Tahun 1998 sebagai perubahan dari Undang-Undang No. 7 Tahun 1992 tentang perbankan, berlakulah dua sistem dalam perbankan yang dilakukan secara konvensional dan atau berdasarkan prinsip syariah (dual banking system) dan khusus bagi bank syariah hanya menggunakan prinsip syariah. Banyak bank yang menjalankan operasionalnya secara prinsip syariah. Terutama setelah dikeluarkannya fatwa bunga haram dari Majelis Ulama Indonesia (MUI) tahun 2003.

Perbedaan prinsip perbankan umum konvensional dengan bank umum syariah terletak pada sistem bunga. Bank syariah dalam menjalankan operasionalnya tidak menggunakan sistem bunga sebagai dasar untuk menentukan imbalan yang diterima atas jasa pembiayaan yang diberikan. Demikian pula imbalan yang diberikan pada nasabah atas dana yang dititipkan kepada bank. Penentuan imbalan yang diinginkan dan yang akan diberikan tersebut sematamata didasarkan pada sistem bagi hasil. Pada bank umum konvensional imbalan 
dalam penghimpunan dana dari masyarakat dihitung dalam bentuk bunga yang dinyatakan dalam persentase tertentu.

Perbedaan antara bank konvensional dan bank syariah secara umum diuraikan sebagai berikut :

\section{Tabel 1}

Perbedaan Bank Syariah dan Bank Konvensional

\begin{tabular}{|c|c|}
\hline Bank Syariah & Bank Konvensional \\
\hline $\begin{array}{l}\text { 1. Melakukan investasi-investasi yang } \\
\text { halal saja } \\
\text { 2. Berdasarkan prinsip bagi hasil, jual } \\
\text { beli, atau sewa } \\
\text { 3. Profit dan falah oriented } \\
\text { (kemakmuran dan kebahagiaan } \\
\text { akhirat) } \\
\text { 4. Hubungan dengan nasabah dalam } \\
\text { bentuk kemitraan } \\
\text { 5. Penghimpunan dan penyaluran dana } \\
\text { harus sesuai dengan fatwa Dewan } \\
\text { Pengawas Syariah (DPS). }\end{array}$ & $\begin{array}{l}\text { 1.Investasi yang halal dan haram } \\
\text { 2. Memakai perangkat bunga } \\
\text { 3.Profit oriented } \\
\text { 4.Hubungan dengan nasabah dalam } \\
\text { bentuk hubungan debitur - } \\
\text { kreditur } \\
\text { 5.Tidak terdapat Dewan Pengawas } \\
\text { Syariah. }\end{array}$ \\
\hline
\end{tabular}

Sumber: Bank Syariah dari teori ke praktek, Syafi'i Antonio,M, 2001.

Keberhasilan suatu bank dalam menjalankan fungsinya sebagai lembaga intermediary sangat ditentukan oleh kemampuan bank tersebut dalam menghimpun dana dari masyarakat yang surplus of fund. Dapat diyakini, sangat sulit bagi suatu bank untuk menyalurkan dana kepada masyarakat yang membutuhkan dana (defisit of fund) tanpa memiliki kemampuan dalam menghimpun dana secara maksimal.

Tabungan adalah salah satu produk penghimpunan dana pada bank syariah. Berdasarkan UU No. 10/1998 tentang perbankan yang dimaksud dengan tabungan adalah "simpanan yang penarikannya hanya dapat dilakukan menurut syarat tertentu tetapi tidak dapat ditarik dengan cek, bilyet giro, dan atau alat yang dipersamakan dengan itu".

Adapun yang dimaksud dengan tabungan syariah adalah tabungan yang dijalankan berdasarkan prinsip syariah. Dalam hal ini Dewan Syariah Nasional telah mengeluarkan fatwa bahwa tabungan yang dibenarkan adalah tabungan yang berdasarkan prinsip mudharabah dan wadiah. Pada bank syariah, setiap produk penghimpunan dana dan pembiayaan bank syariah memiliki spesifikasi sistemnya sendiri.

Keharusan dalam meningkatkan kemampuan menghimpun dana disatu sisi, kebutuhan atau kepentingan nasabah/investor yang beraneka ragam di sisi lainnya, menuntut bank untuk senantiasa melakukan diversifikasi atas produkproduknya dengan berbagai fitur dan layanan yang ditawarkan. Hal ini tentunya dengan harapan, produk-produk yang ditawarkan dapat meraih semua kebutuhan/ kepentingan dari pemilik dana sehingga akan menanamkan dananya pada bank.

Disamping itu, produk yang unggul tidaklah akan membawa hasil yang optimal tanpa diiringi dengan pemahaman yang memadai oleh setiap pegawai 
pada umumnya atau tenaga pemasar pada khususnya dalam menjalankan fungsinya sebagai marketer bagi bank.

Untuk itu, sangat penting adanya Pedoman Pelaksanaan Tabungan Syariah. Karena di samping ditujukan sebagai salah satu wujud pengendalian resiko, Pedoman Pelaksanaan Tabungan Syariah ini juga dimaksudkan untuk meningkatkan pemahaman setiap pegawai terhadap produk-produk penghimpunan dana syariah bank.

Salah satu bank di Indonesia yang saat ini telah berusaha melaksanakan prinsip syariah dalam kegiatan usahanya adalah Bank Nagari, yang merupakan bank milik Pemerintah Daerah Sumatera Barat. Selain menjalankan kegiatan operasionalnya dengan sistem bunga atau konvensional, Bank Nagari juga telah melaksanakan kegiatan usaha berdasarkan prinsip syariah dengan membuka cabang syariah yang tersebar diberbagai Kabupaten/Kota di Sumatera Barat.

Maka berdasarkan latar belakang di atas penulis tertarik untuk melakukan penelitian pada Bank Nagari Cabang Syariah Padang dengan judul "Prosedur Pembukaan Rekening Tabungan pada Bank Nagari Cabang Syariah Padang".

Adapun perumusan masalah dalam penulisan Tugas Akhir ini yaitu bagaimana prosedur pembukaan rekening tabungan pada Bank Nagari Cabang Syariah Padang?

\section{METODE PENELITIAN}

Dalam pengumpulan data dan bahan untuk melakukan penelitian ini digunakan metode - metode pengumpulan data, sebagai berikut:

1. Metode Pengumpulan Data

a. Studi Lapangan (Field Research)

Peninjauan langsung ke objek penelitian yang dipilih untuk meneliti hasil data primer. Penelitian langsung ke lapangan ini akan dapat membantu penulis untuk melengkapi data yang diperlukan. Adapun cara riset lapangan ini adalah dengan mewawancarai langsung pihak-pihak yang berkepentingan dalam hal ini adalah perusahaan atau instansi yang terkait.

b. Studi Perpustakaan (Library Research)

Penelitian yang dilakukan ke perpustakaan berupa buku-buku ilmiah dan tulisan-tulisan yang berhubungan dengan pembahasan yang dilakukan.

2. Metode Analisa Data

Dalam menganalisa data, penulis menggunakan metode analisa data kualitatif sebagai metode penelitian yang menjelaskan secara deskriptif mengenai prosedur pembukaan rekening tabungan pada Bank Nagari Cabang Syariah Padang. Metode analisa ditinjau dari dua segi yang berbeda yaitu antara teori dan praktek yang perlu dipertemukan sehingga dapat diketahui sejauh mana pelaksanaanya, apakah perbedaan yang timbul menyangkut prinsip dasar konsep itu sendiri. Dengan menganalisa perbandingan, pertanyaan itu akan terjawab dan selanjutnya hasil analisa itu dipergunakan sebagai dasar pengambilan kesimpulan dan saran. 


\section{HASIL PENELITIAN DAN PEMBAHASAN \\ Pengertian Bank Syariah}

Perbankan syariah nasional dalam tahun-tahun terakhir ini menunjukkan perkembangan yang relatif cepat. Pesatnya pertumbuhan perbankan syariah ini diimbangi dengan tetap dipertahankannya prinsip kehati-hatian dalam mengelola usahanya, peranan bank syariah menjadi sangat penting karena bank syariah mempunyai landasan etika agar kaum muslimin mendasari segenap aspek kehidupan ekonominya berlandaskan Al-Quran dan As-Sunnah.

Bank berasal dari kata Italia banco yang artinya bangku. Bangku inilah yang dipergunakan oleh bangkir untuk melayani kegiatan operasionalnya kepada para nasabah. Istilah bangku secara resmi dan populer menjadi bank. (Malayu Hasibuhan, 2002:1).

Definisi mengenai bank syari'ah telah banyak dikemukakan. Definisi bank syari'ah menurut Veithzal (2007:33) sebagai berikut: Bank Syariah adalah bank yang melaksanakan kegiatan usaha berdasarkan prinsip syariah yaitu aturan perjanjian berdasarkan hukum Islam antara bank dengan pihak lain untuk penyimpanan dana atau pembiayaan kegiatan usaha, atau kegiatan lainnya yang dinyatakan sesuai dengan syariah.

Menurut Sigit Triandaru dan Totok Budisantoso (2008:153), Bank Syariah adalah bank yang dalam aktifitasnya baik penghimpunan dana maupun dalam rangka penyaluran dananya memberikan dan menekankan imbalan atau dasar prinsip syariah yaitu jual beli dengan bagi hasil.

Menurut UU No. 7 Tahun 1992 yang direvisi dengan UU Perbankan No. 10 Tahun 1998 mendefinisikan bank syari'ah sebagai berikut: Bank syariah adalah lembaga keuangan yang pengoperasiannya dengan sistem bagi hasil.

Masih banyak definisi mengenai bank syariah yang telah dikemukakan oleh para ahli yang pada dasarnya definisi-definisi tersebut tidak berbeda antara satu dengan yang lain, yaitu cara operasionalnya sesuai dengan prinsip syariah Islam. Kalau ada perbedaan hanya terlihat pada usaha bank.

\section{Karakteristik Bank Syariah}

Menurut Muhammad Syafi'i Antonio (2001; 29-34), karakteristik bank syariah yang membedakan antara bank syariah dengan bank konvensional adalah:

1. Ada akad dan aspek legalitas

Dalam bank syariah, akad yang dilakukan memiliki konsekuensi duniawi dan ukhrawi karena akad yang dilakukan berdasarkan hukum Islam. Setiap akad dalam perbankan syariah harus memenuhi ketentuan sebagai berikut :

1) Rukun, seperti: penjual, pembeli, barang, harga, akad/ ijab qabul

2) Syarat, seperti:

a) Barang dan jasa harus halal sehingga transaksi atas barang dan jasa yang haram menjadi batal demi hukum syariah.

b) Harga barang dan jasa harus jelas.

c) Tempat penyerahan harus jelas karena berdampak pada biaya transportasi.

d) Barang yang ditransaksikan harus sepenuhnya dalam kepemilikan. 
2. Terdapat lembaga penyelesaian sengketa

Pada perbankan syariah, apabila terjadi perselisihan antara bank dan nasabah, maka masalah tersebut tidak diselesaikan di pengadilan negeri, tetapi diselesaikan disuatu lembaga sesuai tata cara dan hukum materi syariah.

Di Indonesia lembaga tersebut dikenal dengan Badan Arbitrase Muamalah Indonesia (BAMUI) yang didirikan secara bersama oleh Kejaksaan Agung Republik Indonesia dan Majelis Ulama Indonesia pada tanggal 21 Oktober 1993, yang telah berganti nama pada tanggal 24 Desember 2003 menjadi Badan Arbitrase Syariah Nasional (BASYARNAS).

Untuk menyelesaikan perselisihan antara bank syariah dengan nasabah baik di daerah Kabupaten/Kota maupun Propinsi, BASYARNAS telah memiliki kantor-kantor perwakilan, termasuk Kabupaten/Kota di Sumatera Barat ini.

3. Dalam struktur organisasi terdapat Dewan Pengawas Syariah dan Dewan Syariah Nasional

Dewan Pengawas Syariah memiliki peran untuk mengawasi jalannya operasional bank agar selalu sesuai dengan ketentuan syariah, selain itu Dewan Pengawas Syariah juga menyusun garis panduan bagi kegiatan bank syariah.

Dewan Syariah Nasional memilih fungsi sebagai pengawas produk-produk lembaga keuangan syariah agar sesuai dengan syariah Islam. Selain mengawasi bank syariah, Dewan Syariah Nasional juga mengawasi lembaga syariah lain seperti asuransi syariah, reksadana syariah, modal ventura, dan sebagainya.

4. Bisnis dan usaha yang dibiayai

Bisnis yang dibiayai dalam bank syariah tidak terlepas dari saringan syariah, karena itu bank syariah tidak mungkin membiayai usaha yang di dalamnya terdapat hal-hal yang diharamkan.

5. Lingkungan kerja dan corporate culture

Bank syariah selayaknya memiliki lingkungan kerja yang sejalan dengan syariah. Contohnya dalam berpakaian sudah seharusnya mencerminkan suatu lembaga syariah dengan tidak ada aurat terbuka

\section{Tujuan Bank Syariah}

Tujuan bank syariah menurut Heri Sudarsono (2003:40) diantaranya sebagai berikut:

1. Mengarahkan kegiatan ekonomi umat untuk bermuamalat secara Islami khususnya muamalat yang berhubungan dengan perbankan.

2. Untuk menciptakan suatu keadilan dibidang ekonomi dengan jalan meratakan pendapatan melalui kegiatan investasi.

3. Untuk meningkatkan kualitas hidup umat dengan jalan membuka peluang berusaha yang besar.

4. Untuk menanggulangi masalah kemiskinan, yang telah ada pada umumnya merupakan program utama dari negara-negara yang sedang berkembang. 
5. Untuk menjaga stabilitas ekonomi moneter.

6. Untuk menyelamatkan ketergantungan umat Islam terhadap bank non syariah.

\section{Kegiatan Bank Syariah}

Kegiatan usaha Bank syariah diatur dalam Peraturan Bank Indonesia Nomor 6/24/PBI/2004 tentang bank umum yang melaksanakan kegiatan usaha berdasarkan prinsip syariah.

Pasal 36 mengatur bank wajib menerapkan prinsip syariah dan prinsip kehati-hatian dalam melaksanakan kegiatan usahanya, yakni meliputi sebagai berikut:

1. Melakukan penghimpunan dana dari masyarakat dalam bentuk simpanan dan investasi, antara lain:

1) Giro berdasarkan prinsip wadiah.

2) Tabungan berdasarkan prinsip wadiah atau mudharabah.

3) Deposito berjangka berdasarkan prinsip mudharabah.

2. Melakukan penyaluran dana meliputi sebagai berikut:

1) Prinsip jual-beli berdasarkan akad murabahah, istishna' dan salam.

2) Prinsip bagi hasil berdasarkan akad mudharabah, musyarakah.

3) Prinsip sewa menyewa berdasarkan akad ijarah, ijarah muntahiya bittamlik.

4) Prinsip pinjam meminjam berdasarkan akad qard.

5) Melakukan pemberian jasa pelayanan perbankan berdasarkan prinsip wakalah, hawalah, kafalah, rahn.

6) Membeli, menjual dan/atau menjamin atas resiko sendiri suratsurat berharga pihak ketiga diterbitkan atas dasar transaksi nyata (underlying transaction) berdasarkan prinsip syariah.

7) Membeli surat berharga berdasarkan prinsip syariah yang diterbitkan oleh pemerintah dan/atau Bank Indonesia.

8) Menerbitkan surat berharga berdasarkan prinsip syariah.

9) Memindahkan uang untuk kepentingan sendiri dan/atau nasabah berdasarkan prinsip syariah.

10) Menerima pembayaran tagihan atas surat berharga yang diterbitkan dan melakukan perhitungan dengan atau antar pihak ketiga berdasarkan prinsip syariah.

11) Menyediakan tempat untuk menyimpan barang dan surat-surat berharga berdasarkan prinsip wadiah yad amanah.

12) Melakukan kegiatan penitipan termasuk penataan usahanya untuk kepentingan pihak lain berdasarkan suatu kontrak dengan prinsip wakalah.

13) Memberikan fasilitas letter of credit (L/C) berdasarkan prinsip syariah.

14) Memberikan fasilitas garansi bank berdasarkan prinsip syariah.

15) Melakukan kegiatan usaha kartu debet (change card) berdasarkan prinsip syariah.

16) Melakukan kegiatan wali amanah berdasarkan akad wakalah. 
Pasal 37

17) Melakukan kegiatan lain yang lazim dilakukan bank sepanjang disetujui oleh Bank Indonesia dan mendapatkan fatwa Dewan Syariah Nasional.

1. Selain melakukan kegiatan usaha sebagaimana dimaksud dalam pasal 36, bank dapat pula:

1) Melakukan kegiatan dalam valuta asing berdasarkan akad sharf.

2) Melakukan kegiatan penyertaan modal pada bank atau perusahaan lain dibidang keuangan berdasarkan prinsip syariah seperti sewa guna usaha, modal ventura, perusahaan efek, asuransi serta lembaga kliring penyelesaian dan penyimpanan.

3) Melakukan kegiatan penyertaan modal sementara berdasarkan prinsip syariah untuk mengatasi akibat kegagalan pembiayaan dengan syarat harus menarik kembali penyertaannya dengan ketentuan sebagaimana ditetapkan oleh Bank Indonesia.

4) Bertindak sebagai pendiri dana pensiun dan pengurus dana pensiun berdasarkan prinsip syariah sesuai dengan ketentuan dalam perundang-undangan dana pensiun yang berlaku.

2. Bank syariah dalam melaksanakan fungsi sosial dapat bertindak sebagai penerima dana sosial antara lain dalam bentuk zakat, infaq, shadaqah, wakaf, hibah dan menyalurkannya sesuai syariah atas nama bank atau lembaga amil zakat yang ditunjuk oleh pemerintah.

Pasal 38

1. Bank wajib mengajukan permohonan persetujuan kepada Bank Indonesia atas produk dan jasa baru yang akan dikeluarkan.

2. Permohonan persetujuan atas produk dan jasa baru yang dikeluarkan sebagaimana dimaksud pada ayat (1) wajib dilampiri dengan fatwa Dewan Syariah Nasional.

Pasal 39

1. Bank dilarang melakukan kegiatan usaha perbankan secara konvensional.

2. Bank dilarang mengubah kegiatan usaha menjadi bank konvensional.

Dari uraian di atas dapat disimpulkan bahwa produk perbankan syariah dapat dibagi menjadi tiga bagian yaitu: produk penghimpunan dana, produk penyaluran dana, dan produk yang berkaitan dengan jasa yang diberikan perbankan kepada nasabahnya.

\section{Pengertian Bagi Hasil}

Bagi hasil menurut terminologi asing (bahasa Inggris) dikenal dengan profit sharing. Profit dalam kamus ekonomi diartikan pembagian laba. Secara definisi profit sharing diartikan sebagai distribusi beberapa bagian dari laba pada pegawai dari suatu perusahaan.

Adapun bagi hasil menurut Muhammad Syafi'i Antonio (2000:192), bagi hasil adalah suatu cara pembagian hasil usaha antara penyedia dana dan pengelola dana, pembagian hasil ini dapat terjadi antara bank dengan penyimpan dana maupun antara bank dengan nasabah penerima dana. 


\section{Nisbah}

Nisbah keuntungan adalah salah satu rukun yang khas dalam akad mudharabah, yang tidak ada dalam akad jual beli. Nisbah ini mencerminkan imbalan yang berhak diterima oleh kedua belah pihak yang bermudharabah. Mudharib mendapatkan imbalan atas kerjanya, sedangkan shahibul mal mendapatkan imbalan atas penyertaan modalnya. Nisbah keuntungan inilah yang akan mencegah terjadinya perselisihan antara kedua pihak mengenai cara pembagian keuntungan, adapun nisbah keuntungan harus dinyatakan dalam bentuk persentase antara kedua belah pihak, bukan dinyatakan dalam nilai nominal tertentu.

Penentuan besarnya nisbah ditentukan berdasarkan kesepakatan masingmasing pihak yang berkontrak, tetapi dalam prakteknya di perbankan modern, tawar-menawar nisbah antara pemilik modal yakni investor atau deposan dengan bank syariah hanya terjadi bagi deposan/investor dengan jumlah besar, karena mereka ini memiliki daya tawar yang relatif tinggi. Kondisi seperti ini sebagai spesial nisbah, sedangkan untuk nasabah deposan kecil tawar-menawar tidak terjadi. Bank syariah akan mencantumkan nisbah yang ditawarkan, deposan boleh setuju boleh tidak. Bila setuju maka ia akan melanjutkan menabung, sebaliknya bila tidak setuju dipersilahkan mencari bank syariah lain yang menawarkan nisbah lebih menarik.

\section{Prosedur Pembukaan Rekening Tabungan}

Secara umum prosedur pembukaan rekening Tabungan Sikoci Syariah, Tabungan Tahari Syariah, dan TabunganKu Syariah hampir sama, baik ketentuan pokok tabungan maupun prosedur pelaksanaanya.

\section{Ketentuan Pokok Tabungan}

\section{Kriteria pemohon}

a. Perorangan/Badan Hukum/Badan Usaha.

b. Beragama Islam (khusus calon nasabah tabungan Tahari Syariah).

c. Cakap melakukan perbuatan hukum.

d. Berdomisi atau berkedudukan di wilayah kerja bank.

e. Warga Negara Indonesia (WNI) antau Warga Negara Asing (WNA).

\section{Persyaratan permohonan}

a. Menyerahkan foto copy identitas diri (KTP/SIM) bagi Warga Negara Indonesia (WNI), Passport dan Surat Izin Tinggal Sementara bagi Warga Negara Asing (WNA).

b. Mengisi permohonan pembukaan rekening tabungan yang telah disediakan.

c. Menyerahkan foto copy akta pendirian perusahaan berikut perubahan, perizinan usaha khusus bagi nasabah berbentuk perusahaan/badan usaha.

d. Menyerahkan foto copy Nomor Pokok Wajib Pajak (NPWP) perusahaan bagi nasabah berbentuk badan usaha.

e. Mengisi Formulir Data Nasabah (FDN) yang telah disediakan.

f. Semua dokumen asli dibawa untuk legalisasi. 


\section{Persyaratan Produk Tabungan}

a. Jenis Tabungan

a) Tabungan Sikoci Syariah dengan akad wadiah.

b) Tabungan Sikoci Syariah dengan akad mudharabah.

c) Tabungan Tahari Syariah dengan akad wadiah.

d) Tabungan Tahari Syariah dengan akad mudharabah.

e) TabunganKu Syariah dengan akad wadiah.

b. Setoran Awal

a) Setoran awal Sikoci Syariah ditetapkan minimal sebesar Rp 25.000,- (dua puluh lima ribu rupiah).

b) Setoran awal Tahari Syariah ditetapkan minimal sebesar Rp 500.000,- (lima ratus ribu rupiah).

c) Setoran awal TabunganKu Syariah ditetapkan minimal sebesar Rp 20.000,- (dua puluh ribu rupiah).

c. Saldo Minimal

a) Saldo minimal Sikoci Syariah ditetapkan minimal sebesar Rp 25.000,- (dua puluh lima ribu rupiah).

b) Saldo minimal Tahari Syariah ditetapkan minimal sebesar $\mathrm{Rp}$ 500.000,- (lima ratus ribu rupiah).

c) Saldo minimal TabunganKu Syariah ditetapkan minimal sebesar Rp 20.000,- (dua puluh ribu rupiah).

d. Jasa Tabungan

a) Pemberian bonus untuk tabungan yang berprinsip wadiah.

1. Bank Nagari Syariah tidak menjanjikan pemberian jasa atau bonus kepada nasabah.

2. Pemberian imbalan atau bonus dapat diberikan kepada nasabah ditetapkan dengan Surat Direksi.

3. Apabila bank memutuskan untuk memberikan jasa atau bonus pada tabungan yang berprinsip wadiah, maka pemberian bonus dihitung dari saldo rata-rata dengan formula sebagai berikut:

$$
\text { Bonus }=\text { Saldo Rata-Rata Harian } \times \text { EQ Rate }
$$

Besaran EQ Rate berdasarkan Surat Direksi tersendiri.

4. Atas jasa atau bonus tabungan berprinsip wadiah yang diberikan, diperhitungkan pajak atas bonus tersebut sesuai ketentuan berlaku.

b) Bagi hasil tabungan yang berprinsip mudharabah

1. Besaran nisbah bagi hasil tabungan yang berprinsip mudharabah beserta perubahannya ditetapkan dengan Surat Direksi tersendiri dan untuk pertama kalinya ditetapkan sebesar $35 \%$ untuk nasabah.

2. Perhitungan bagi hasil untuk tabungan yang berprinsip mudharabah dilakukan setiap akhir bulan yang dihitung 
berdasarkan saldo rata-rata setiap bulan yang diberikan dari hasil pendapatan penyaluran dana atau reveneu sharing.

$$
=\frac{\text { Sagi Hasil }}{\text { Saldo Rata }- \text { Rata Harian } \times \text { Hasil Pendapatan } \times \text { Nisbah }}
$$

3. Pemindahbukuan bagi hasil ke dalam rekening tabungan dilaksanakan pada akhir bulan yang sama.

4. Perhitungan bagi hasil dan pemindahbukuan bagi hasil dilaksanakan secara otomatis oleh sistem.

5. Atas jasa atau bagi hasil tabungan berprinsip mudharabah diperhitungkan pajak dan atau zakat atas bagi hasil sesuai ketentuan berlaku.

e. Biaya Administrasi

Biaya administrasi Tabungan Sikoci Syariah ditetapkan sebesar Rp 2.500,- (dua ribu lima ratus rupiah). Untuk Tabungan Tahari Syariah dan TabunganKu Syariah tidak dikenakan biaya administrasi.

f. Biaya Penutupan Rekening

Biaya penutupan rekening Tabungan Sikoci Syariah ditetapkan sebesar Rp 5.000,- (lima ribu rupiah). Untuk Tabungan Tahari Syariah dan TabunganKu Syariah tidak dikenakan biaya penutupan rekening.

g. Biaya Penggantian Buku Hilang

Biaya penggantian buku hilang Tabungan Sikoci Syariah ditetapkan sebesar Rp 5.000,- (lima ribu rupiah). Untuk Tabungan Tahari Syariah dan TabunganKu Syariah tidak dikenakan biaya penggantian buku tabungan.

4. Daerah Pelayanan

Daerah pelayanan terkait produk Tabungan Sikoci Syariah, Tabungan Tahari Syariah, dan Tabunganku Syariah adalah pada seluruh Kantor Cabang Syariah, Kantor Cabang Pembantu, Kantor Kas, dan Kantor Layanan Syariah (Office Channeling) Bank Nagari.

\section{Syarat Penyetoran}

Penyetoran dapat dilakukan secara tunai/pemindahbukuan ke rekening tabungan pada seluruh kantor cabang Bank Nagari.

\section{Syarat Penarikan}

a. Penarikan tunai dari rekening tabungan dapat dilakukan pada seluruh kantor cabang dengan menggunakan warkat/slip penarikan dan buku tabungan.

b. Penarikan tunai bukan dilakukan oleh yang bersangkutan, maka harus disertai dengan Surat Kuasa.

c. Penarikan melalui mesin Anjungan Tunai Mandiri (ATM).

d. Untuk Tabungan Tahari Syariah penarikan melalui pemindahbukuan dengan menggunakan surat perintah pemindahbukuan atas beban rekening penabung untuk rekening giro Departemen Agama RI di Bank Nagari untuk pengambilan porsi dan pelunasan. Penarikan 
melalui pemindahbukuan dengan menggunakan formulir pemindahbukuan yang telah ditetapkan oleh bank ke rekening giro Departemen Agama RI.

e. Calon jemaah haji membatalkan keberangkatan menunaikan ibadah haji.

f. Calon jemaah haji meninggal dunia.

g. Calon jemaah haji berangkat menunaikan ibadah haji.

7. Syarat Penutupan Rekening

Penutupan atas rekening tabungan dilakukan antara lain apabila:

a. Pemegang rekening mengajukan permintaan penutupan rekening secara tertulis.

b. Untuk Tabungan Tahari Syariah penutupan rekening dilakukan apabila saldo nasabah telah mencukupi untuk keberangkatan ke Tanah Suci Mekkah.

c. Pemegang rekening meninggal dunia.

Pencairan/pentransferan dana oleh ahli waris dapat dilaksanakan dengan menunjukkan Surat Keterangan Ahli Waris yang sah dari pejabat.

Biaya atas penutupan rekening sesuai dengan ketentuan yang berlaku.

\section{Akad/Perjanjian}

Kesepakatan atas pembukaan tabungan atas dasar akad mudharabah dan wadiah dituangkan dalam akad/perjanjian.

\section{Prosedur Pelaksanaan}

\section{Prosedur Pembukaan Rekening}

a. Permohonan

Setiap pembukaan rekening tabungan didahului dengan permohonan oleh nasabah dengan tata cara dan berkas permohonan sebagai berikut:

1) Tata cara permohonan

a) Nasabah mengajukan permohonan pembukaan rekening tabungan kepada kantor cabang syariah atau kantor cabang konvensional yang mempunyai layanan syariah (Office Channeling).

b) Permohonan pembukaan tabungan diajukan secara tertulis dengan memakai formulir yang telah disediakan bank.

c) Setiap penerimaan permohonan pembukaan tabungan dicatat pada buku registrasi dan diberikan nomor registrasi untuk dimintakan disposisi pejabat yang berwenang.

2) Berkas permohonan

Permohonan yang diajukan dilengkapi dengan berkas/dokumen sebagaimana yang telah diatur dalam persyaratan permohonan.

b. Identifikasi dan analisis

Atas permohonan yang diterima selanjutnya dilakukan identifikasi dan analisis atas permohonan pembukaan rekening tabungan sesuai prosedur berikut: 
1) Meneliti keabsahan/kebenaran permohonan dan kelengkapan lampiran permohonan.

2) Meminta nasabah menandatangani blanko speciment yang telah disediakan.

3) Meneliti kesesuaian tanda tangan pada blanko speciment dengan tanda pengenal nasabah.

4) Untuk nasabah berbentuk badan usaha identifikasi dan analisa juga dilakukan dalam bentuk mengumpulkan data dan informasi guna menentukan kewenangan/kapasitas pemohon dalam pembukaan rekening tabungan pada bank.

c. Realisasi

Atas permohonan yang berdasarkan hasil identifikasi dan analisis dinilai sudah memenuhi ketentuan, selanjutnya Customer Service atau petugas dana melakukan proses sebagai berikut:

1) Customer Service atau petugas dana meng- entry data pokok nasabah dan data master rekening pada Sistem Akuntansi Bank.

2) Pemimpin bagian/seksi yang berwenang melakukan verifikasi dan validasi atas data entry yang telah dilakukan.

3) Nasabah melakukan setoran awal sesuai dengan persyaratan di atas.

d. Dokumentasi

Customer Service atau petugas dana melakukan dokumen atas seluruh dokumen yang terkait dengan pembukaan rekening tabungan, yang antara lain meliputi:

1) Aplikasi pemohonan dan lampirannya.

2) Menandatangani akad/perjanjian pembukaan rekening tabungan.

3) Blanko speciment yang telah ditandatangani.

4) Formulir Data Nasabah (FDN).

5) Formulir Data Nasabah Tahari.

6) Surat Kuasa Pemindahbukuan dari Rekening Tahari ke Rekening DEPAG RI.

\section{Prosedur Penerimaan Setoran Tunai}

a. Penyetoran tunai ke Teller

1) Penyetoran atas rekening tabungan dengan menggunakan bukti/slip penyetoran yang telah disediakan bank, kemudian menyerahkan kepada Teller dengan menyertakan buku tabungan.

2) Teller memeriksa kelengkapan dan keabsahan bukti/slip setoran yang diserahkan.

3) Teller menerima dan menghitung kecukupan uang sesuai jumlah yang tertera pada bukti/slip setoran di hadapan penyetor.

4) Teller melakukan proses posting transaksi ke dalam Sistem Akuntansi Bank sesuai kewenangan.

5) Teller mencetak hasil posting setoran ke Sistem Akuntansi Bank pada bukti/slip setoran untuk selanjutnya diparaf.

6) Serahkan lembaran kedua (lembaran untuk nasabah) bukti/slip setoran. 
b. Penyetoran melalui pemindahbukuan

Pemindahbukuan pada rekening tabungan yang bersangkutan tanpa dikenakan perhitungan biaya.

\section{Prosedur Penarikan}

a. Penarikan tunai

1) Penarikan atas rekening tabungan dilakukan dengan menggunakan surat perintah pembayaran dan hanya dapat dilakukan oleh pemegang rekening/pihak yang diberi kuasa oleh pemegang rekening.

2) Teller memeriksa kelengkapan dan keabsahan bukti penarikan yang diserahkan apabila telah memenuhi persyaratan sebagai berikut:

a) Penulisan tempat dan tanggal tarik pada lembaran tabungan telah benar.

b) Penulisan jumlah dalam angka telah sama dengan penulisan jumlah dalam huruf.

c) Setiap koreksi penulisan pada lembaran tabungan telah ditandatangani oleh pemilik rekening.

d) Tabungan telah ditandatangani oleh pemilik.

e) Bagi pemegang rekening tergolong badan usaha (seperti: CV, PT, Koperasi, Yayasan dan sejenisnya) bilyet giro/tabungan telah dibubuhi stempel perusahaan.

f) Tanda tangan yang tercantum pada lembaran bilyet giro/tabungan sama dengan contoh tanda tangan pemegang rekening yang terdapat pada arsip bank.

g) Dana yang tersedia dalam rekening harus mencukupi untuk memenuhi kewajiban atas penarikan yang dilakukan.

h) Penarikan tabungan harus disertai dengan penyerahan kartu/buku tabungan.

3) Teller melakukan proses posting transaksi ke Sistem Akuntansi Bank sesuai kewenangan.

4) Teller mencetak hasil posting penarikan ke Sistem Akuntansi Bank pada bukti/slip penarikan untuk selanjutnya diparaf.

5) Teller menyerahkan uang sesuai dengan jumlah yang tertera pada bukti/slip penarikan.

b. Penarikan melalui pemindahbukuan

1) Penarikan melalui pemindahbukuan dilakukan langsung atas rekening tabungan yang bersangkutan dengan mengkredit rekening yang ditunjuk sesuai dengan bukti pemindahbukuan (nota) dan Surat Kuasa dari pemegang rekening.

2) Pemindahbukuan pada rekening tabungan yang bersangkutan tanpa dikenakan biaya.

\section{Prosedur Penutupan Rekening}

a. Penutupan rekening atas permintaan pemegang rekening atau karena pembatalan menunaikan haji. 
1) Permintaan penutupan rekening dan pemegang rekening dilakukan secara tertulis.

2) Customer Service atau petugas dana menerima dan meregistrasi surat permintaan penutupan rekening.

3) Customer Service atau petugas dana menghitung dan membuat warkat pembebanan atas biaya penutupan rekening, biaya administrasi dan biaya lainnya sesuai ketentuan berlaku.

4) Customer Service atau petugas dana meneliti/memeriksa kewajiban-kewajiban atau pos-pos yang belum diperhitungkan, bila ada maka kewajiban dimaksud telah diselesaikan sebelum penutupan rekening dilaksanakan.

5) Customer Service atau petugas dana meminta pemilik rekening untuk mengisi dan menandatangani bukti/slip penarikan sejumlah sisa dana setelah diperhitungkan kewajibannya.

6) Customer Service menyerahkan warkat-warkat terkait penutupan rekening kepada Teller.

7) Teller melakukan proses tutup rekening pada Sistem Akuntansi Bank serta memposting warkat-warkat terkait lainnya untuk selanjutnya menyerahkan sisa uang kepada pemilik rekening.

8) Customer Service atau petugas dana mencetak mutasi rekening untuk kebutuhan dokumentasi bagi bank.

Prosedur di atas berlaku untuk nasabah Tabungan Sikoci Syariah, TabunganKu Syariah dan untuk nasabah Tabungan Tahari Syariah yang belum terdaftar di SISKOHAT. Jika penabung telah terdaftar di SISKOHAT atau telah melunasi BPIH prosedurnya sebagai berikut:

1) Penabung yang batal karena alasan tertentu mengajukan surat permohonan pembatalan kepada Kantor Departemen Agama Kabupaten/Kota domisili penabung.

2) Kantor Departemen Agama Kabupaten/Kota membayarkan dana penabung yang telah dipindahbukukan ke Rekening Departemen Agama RI sesuai ketentuan yang berlaku.

3) Jika masih ada saldo tabungan penabung maka dibayarkan kepada penabung setelah diperhitungkan balas jasa yang berjalan dan biaya lainnya (jika ada).

b. Pemegang rekening meninggal dunia

1) Setelah mendapat pemberitahuan dari keluarga bahwa pemegang rekening meninggal dunia yang disertai dengan akte/Surat Keterangan Kematian, Customer Service atau petugas dana memblokir rekening pada Sistem Akuntansi Bank agar tidak dapat dilakukan pendebetan sebagai salah satu langkah antisipatif atas resiko penyalahgunaan blanko formulir bank yang belum digunakan oleh almarhum.

2) Penutupan rekening dilakukan setelah ahli waris menyerahkan Surat Keterangan Ahli Waris yang sah sesuai ketentuan yang berlaku dan surat permohonan penutupan rekening. 
3) Customer Service atau petugas dana menghitung dan membuatkan warkat pembebanan atas biaya penutupan rekening, biaya administrasi dan biaya lainnya sesuai ketentuan berlaku.

4) Customer Service atau petugas dana meneliti/memeriksa kewajiban-kewajiban atau pos-pos yang belum diperhitungkan, bila ada maka kewajiban dimaksud telah diselesaikan sebelum penutupan rekening kepada Teller.

5) Customer Service atau petugas dana meminta ahli waris yang sah untuk mengisi dan menandatangani bukti/slip penarikan sejumlah sisa dana setelah diperhitungkan kewajibannya.

6) Customer Service menyerahkan warkat-warkat terkait penutupan rekening kepada Teller.

7) Teller melakukan proses tutup rekening pada Sistem Akuntansi Bank serta memposting warkat-warkat terkait lainnya untuk selanjutnya menyerahkan sisa uang kepada ahli waris.

8) Customer Service atau petugas dana mencetak mutasi rekening untuk kebutuhan dokumentasi bagi bank.

Prosedur di atas berlaku untuk nasabah Tabungan Sikoci Syariah, TabunganKu Syariah dan untuk nasabah Tabungan Tahari Syariah yang belum terdaftar di SISKOHAT. Jika penabung telah terdaftar di SISKOHAT atau telah melunasi BPIH prosedurnya sebagai berikut:

1) Ahli waris dari penabung yang meninggal dunia mengajukan surat permohonan pembatalan kepada Kantor Departemen Agama Kabupaten/Kota domisili penabung yang meninggal dunia.

2) Kantor Departemen Agama Kabupaten/Kota membayarkan dana penabung yang telah dipindahbukukan ke Rekening Departemen Agama RI sesuai dengan ketentuan yang berlaku.

3) Jika masih ada saldo tabungan dari penabung yang meninggal dunia maka dibayarkan kepada ahli waris yang telah ditunjuk sebelumnya setelah diperhitungkan balas jasa yang berjalan dan biaya lainnya (jika ada).

c. Rekening tidak aktif

1) 2 (dua) bulan sebelum tanggal penutupan rekening, Customer Service atau petugas dana menyiapkan surat pemberitahuan rekening pasif, untuk selanjutnya menyampaikan surat pemberitahuan tersebut kepada si pemilik rekening. Surat dimaksud diantaranya berisikan sebagai berikut:

a) Pemberitahuan rekening tabungan tidak aktif.

b) Permintaan untuk mengaktifkan kembali rekening dimaksud.

c) Pemberitahuan bahwa rekening akan ditutup jika dalam waktu 30 hari kalender terhitung tanggal surat pemberitahuan masih dinilai tidak aktif.

2) Customer Service atau petugas dana menghitung dan membuatkan warkat (nota) pembebanan atas biaya penutupan rekening, biaya administrasi dan biaya lainnya sesuai ketentuan berlaku. 
3) Customer Service atau petugas dana meneliti/memeriksa kewajiban-kewajiban atau pos-pos yang belum diperhitungkan, bila ada maka kewajiban dimaksud telah diselesaikan sebelum penutupan rekening dilaksanakan.

4) Customer Service atau petugas dana menghitung dan membuatkan warkat (nota) pemindahbukuan rekening ke rekening "Sikoci Syariah Pasif” atau "Tabunganku Syariah Pasif"

5) Customer Service menyerahkan warkat-warkat terkait penutupan rekening kepada Teller untuk dilakukan posting pada Sistem Akuntansi Bank.

6) Teller melakukan proses tutup rekening pada Sistem Akuntansi Bank serta memposting warkat-warkat terkait lainnya, termasuk pemindahbukuan rekening ke rekening "Sikoci Syariah Pasif" atau Tabungaku Syariah Pasif" pada Sistem Akuntansi Bank.

7) Customer Service atau petugas dana membuat surat pemberitahuan ke pemilik rekening tentang rekening tabungan pada bank telah ditutup dan memintanya untuk segera mengambil saldo rekeningnya, maka yang bersangkutan dikenakan biaya administrasi setiap bulan sesuai buku tarif terhitung sejak rekeningnya ditutup sampai dengan saldonya menjadi NIHIL.

d. Penutupan dilakukan pada saat pelunasan BPIH

1) Tabungan harus ditutup jika telah digunakan untuk pelunasan BPIH.

2) Sisa saldo tabungan setelah digunakan untuk pelunasan BPIH harus dipindahkan ke rekening tabungan lainnya atau diambil tunai oleh penabung.

\section{Prosedur Pendaftaran Haji}

a. Petunjuk Pelaksanaan Aplikasi SISKOHAT mempedomani Surat Direksi No. SR/302/DIR/CB/10-2008 tanggal 30 Oktober 2008 perihal Petunjuk Pelaksanaan Aplikasi SISKOHAT.

b. Apabila terdapat perubahan pada Petunjuk Pelaksanaan Aplikasi SISKOHAT ini, maka akan ditetapkan dengan Surat Direksi tersendiri.

\section{Prosedur Pemblokiran Rekening Tabungan}

a. Pemblokiran karena permintaan penabung dikarenakan hilangnya buku tabungan dan pemblokiran dilakukan atas dasar surat permohonan dari nasabah yang bersangkutan.

b. Pemblokiran karena penyitaan oleh Kejaksaan/Kepolisian/Pengadilan dan Bank Indonesia.

Pemblokiran yang berkaitan dengan perkara pidana dan atau perdata dilakukan atas dasar surat perintah pemblokiran dari pihak yang berwajib (polisi, jaksa, hakim).

\section{Prosedur Penggantian Buku Hilang}

a. Apabila nasabah kehilangan buku tabungan, maka nasabah harus segera melaporkan kehilangan kepada bank secara tertulis dan 
dilengkapi dengan Surat Keterangan Hilang yang diterbitkan oleh Kepolisian.

b. Bank berdasarkan laporan Kepolisian menutup rekening tabungan yang bersangkutan dan membuka rekening tabungan baru sebagai pengganti.

c. Penggantian rekening dilakukan berdasarkan persetujuan Pemimpin Cabang atau pejabat yang berwenang.

d. Persetujuan Pemimpin Cabang atau pejabat yang berwenang diberikan setelah diyakini bahwa:

1) Pihak yang melaporkan adalah penabung yang tercatat pada administrasi bank.

2) Tanda tangan pada laporan kehilangan cocok dengan contoh tanda tangan penabung yang tersimpan pada administrasi bank.

3) Surat Keterangan Hilang diterbitkan oleh pihak Kepolisian.

e. Pada buku tabungan yang baru harus dibubuhkan stempel "Pengganti Rekening No. XXX”

f. Seluruh rekening tabungan yang ditutup karena kartu/buku tabungan hilang harus dicatat dalam buku registrasi untuk kontrol atas penyalahgunaan tabungan oleh pihak lain tidak berkepentingan.

g. Bank dibebaskan dari segala kerugian atau tuntutan yang timbul karena kehilangan/pemalsuan atau penyalahgunaan buku tabungan.

\section{KESIMPULAN}

Berdasarkan uraian pada bab-bab sebelumnya, maka dapat diambil kesimpulan sebagai berikut:

1. Bank Nagari Cabang Syariah Padang merupakan badan/lembaga keuangan yang menjalankan kegiatan usahanya berdasarkan prinsip syariat Islam. Yang didirikan dengan maksud dan tujuan yakni untuk membantu dan mendorong pertumbuhan perekonomian dan pembangunan daerah.

2. Produk dan Jasa yang ditawarkan oleh Bank Nagari Cabang Syariah Padang adalah:

1) Penghimpunan dana, meliputi:

a. Giro Wadiah iB

b. Tabungan Sikoci Wadiah iB

c. Tabungan Sikoci Mudharabah iB

d. Tabungan Tahari Wadiah iB

e. Tabungan Tahari Mudharabah iB

f. Tabungan $\mathrm{Ku}$ iB

g. Deposito Mudharabah iB

2) Pembiayaan, meliputi:

a. Murabahah iB Plus

b. Murabahah Modal Kerja iB

c. Murabahah iB Investasi

d. Pembiayaan iB kepada Koperasi

e. Pembiayaan Modal Kerja Kontraktor iB

f. Pembiayaan Jual Beli iB Istishna' 
g. Pembiayaan Ijarah dan Ijarah Muntahiyah iB Al-tamlik (IMBT)

h. Gadai iB Emas

3) Jasa dan Layanan meliputi:

a. Sharf yaitu jual beli Valas

b. Ijarah dalam bentuk Save Deposit Box

c. Wakalah dalam bentuk Transfer

3. Prosedur Pembukaan Rekening Tabungan Pada Bank Nagari Cabang Syariah Padang adalah sebagai berikut:

1) Tahap Permohonan

2) Tahap Identifikasi dan analisis

3) Tahap Realisasi

4) Tahap Dokumentasi

\section{DAFTAR PUSTAKA}

Afrianto, D., \& Afriyeni, A. (2019). Aktivitas Penghimpunan Dana Tabungan Pada PT. Bank Pembangunan Daerah (BPD) Sumatera Barat Cabang Utama Padang. https://doi.org/10.31219/osf.io/ackfh

Alanshari, F., \& Marlius, D. (2018). Prosedur Pemberian Kredit KPR Pada PT. Bank Tabungan Negara (Persero) TBK Cabang Pembantu Bukittinggi. https://doi.org/10.31227/osf.io/rsfhc

Albone, Abdul Aziz, dkk. (2009). Panduan Penyusunan Proposal Penelitian dengan Mudah. Yayasan Jihadul Khair Center: Padang.

Ascarya, (2007). Akad dan Produk Bank Syariah, Raja Grafindo Persada. Jakarta.

Bank Pembangunan Daerah Sumatera Barat. (2012). Sejarah berdirinya, visi dan misi, struktur organisasi dan peraturan pelaksanaan prosedur pembukaan rekening PT. BPD Sumatera Barat.

Dendawijaya, Lukman. (2008). Manajemen Perbankan, Gramedia Indonesia , Jakarta

Departemen Pendidikan Nasional.(2002). Kamus Besar Bahasa Indonesia, Balai Pustaka,Jakarta,

Fernandes, Y. D., \& Marlius, D. (2018). Peranan Customer Service Dalam Meningkatkan Pelayanan Kepada Nasabah Pada PT. Bank Pembangunan Daerah Sumatera Barat Cabang Utama Padang. https://doi.org/10.31227/osf.io/wrh3p

Hidayati, R. R., \& Marlius, D. (2018). Aktivitas Promosi Dalam Meningkatkan Dana Pihak Ketiga Pada PT. Bank Perkreditan Rakyat (BPR) Batang Kapas Pesisir Selatan. https://doi.org/10.31227/osf.io/8dgqn 
Kasmir. (2011). Bank dan Lembaga Keuangan Lainnya. PT. Raja Grafindo Persada: Jakarta.

Lidya Martha, dkk. (2007). Pedoman Penulisan Proposal, Tugas Akhir dan Skripsi. AKBP - STIE “KBP” : Padang.

Marlius, D. (2018). Loyalitas Nasabah Bank Nagari Syariah Cabang Bukittinggi Dilihat Dari Kualitas Pelayanan. Jurnal Pundi. Volume 1. No. 3. Hal.12-22. https://doi.org/10.31575/jp.v1i3.60

Rigawan, G., \& Afriyeni, A. (2019). Penerapan Sistem Informasi Bank Pada PT. Bank Central Asia Tbk (BCA). https://doi.org/10.31219/osf.io/yhx7v

Syafe i Antonio, Muhammad. (2001). Bank Syariah dari Teori ke Praktek. Jakarta: Gema Insani.

Tim Pengembangan Perbankan Syariah IBI. (2001). Konsep, Produk, dan Implementasi Operasional Bank Syariah. Djambatan. Jakarta

Wahyuni, S. V., \& Afriyeni, A. (2019). Aktivitas Penghimpunan Dana Deposito Pada PT. Bank Pembangunan Daerah (BPD) Sumatera Barat Cabang Lintau. https://doi.org/10.31219/osf.io/g67d2

Widayati, R. (2019). Aktivitas Pemasaran Produk Tabungan Pada PT. Bpr Rangkiang Denai Payakumbuh Barat. https://doi.org/10.17605/OSF.IO/S3UZM

Widayati, R. (2019). Aktivitas Pemasaran Produk Simpanan PT. Bank Tabungan Negara (Persero) Tbk Kantor Cabang Padang. https://doi.org/10.17605/OSF.IO/3Z5YC 